\title{
HERITABILITY AT FAMILY MEAN LEVEL ${ }^{1}$
}

\author{
José Marcelo Soriano Viana²
}

\begin{abstract}
Based on a polygenic system of a diploid species, without epistasis, and a population in HardyWeinberg equilibrium, without inbreeding and under linkage equilibrium, it can be shown that: (1) the narrow sense heritability at half-sib family level is equal to the square of the correlation coefficient between family mean and the additive genetic value of its common parent; (2) the narrow sense heritability at full-sib family level is equal to the square of the correlation coefficient between family mean and the mean of the additive genetic values of its parents; (3) the narrow sense heritability at $S_{n}$ family level is exactly equal to the square of the correlation coefficient between family mean and the additive genetic value of its parent only in absence of dominance or when allele frequencies are equal; and (4) the broad sense heritability at full-sib or $S_{n}$ family level can be used to analyze selection efficiency, since the progeny genotypic mean is, in general, a good indicator of parents, or $\mathrm{S}_{\mathrm{n}-1}$ plant superiority with respect to the frequency of favorable genes.
\end{abstract}

Key words: Quantitative genetics, plant breeding, selection.

\section{HERDABILIDADE EM NÍVEL DE MÉDIA DE FAMÍLIA}

\begin{abstract}
RESUMO - Considerando um sistema poligênico de uma espécie diplóide, sem epistasia, e uma população em equilíbrio de Hardy-Weinberg, não-endogâmica, e em equilíbrio de ligação gênica, demonstra-se que: 1) a herdabilidade em sentido restrito em nível de família de meios-irmãos é igual ao quadrado do coeficiente de correlação entre a média fenotípica de família e o valor genético aditivo do pai comum; 2) a herdabilidade em sentido restrito em nível de família de irmãos completos é igual ao quadrado do coeficiente de correlação entre a média fenotípica de família e a média dos valores genéticos aditivos dos progenitores; 3) a herdabilidade em sentido restrito em nível de família $S_{n}$ é exatamente igual ao quadrado do coeficiente de correlação entre a média fenotípica de família e o valor genético aditivo de seu progenitor, somente na ausência de dominância ou quando as freqüências alélicas são iguais; $e$ 4) a herdabilidade em sentido amplo em nível de família de irmãos completos ou $S_{n}$ pode ser usada para analisar a eficiência da seleção, pois, em geral, a média genotípica da progênie é um bom indicador da superioridade dos pais ou da planta $S_{n-1}$, em termos de freqüência dos genes favoráveis.
\end{abstract}

Palavras-chave: Genética quantitativa, melhoramento vegetal e seleção.

\section{INTRODUCTION}

The narrow sense heritability of a trait, in relation to a reference population and under a certain environmental condition, is one of the most important genetic parameters, as the expected gain with selection of the best individuals or families is directly proportional to its value (Wricke \& Weber, 1986; Hallauer \& Miranda Filho, 1981). Generally, the broad and narrow sense heritabilities in plants and animals are interpreted as proportions of the phenotypic variance among selection units, due to differences between their genotypic or additive genetic values, respectively. These definitions have been widely discussed for use in plant breeding

1 Recebido para publicação em 20.7.2000.

Aceito para publicação em 29.6.2002.

2 Eng.-Agr., D.S., Departamento de Biologia Geral da Universidade Federal de Viçosa - UFV, 36571-000 Viçosa-MG. <jmsviana@mail.ufv.br>. 
(Hanson, 1963; Dudley \& Moll, 1969; Nyquist, 1991). However, there are further and more interesting ways of interpreting heritability. For example, the narrow sense heritability at individual level in a base population is equal to the square of the correlation coefficient between the phenotypic and the additive genetic values of the same individual in the population (Falconer \& Mackay, 1996). Therefore, the greater the heritability, the closer to unit will the correlation between the phenotypic value of an individual and its additive genetic value be. This heritability is an indicator of the number of favorable genes possessed by the individual (in general, the greater the additive genetic value of an individual, the greater the number of genes that increase trait expression) (Falconer \& Mackay, 1996). Therefore, when narrow sense heritability at individual level is high, mass selection is adequate because the phenotypic value of an individual is an excellent indicator of the number of desirable genes it possesses. However, in plant breeding, one of the most important concepts is the narrow sense heritability at family level. This paper covers the discussion on the interpretation and use of this concept.

\section{METHODS, RESULTS AND DISCUSSION}

Consider a polygenic system with $\mathrm{k}$ genes, with two alleles each, without epistasis, and responsible for the expression of a trait in a diploid species, and a population in Hardy-Weinberg equilibrium, not inbred, and in linkage equilibrium.

\subsection{Correlation between half-sib family phenotypic value and the additive genetic value of its common parent}

Take, initially, one of the $\mathrm{k}$ genes, with alleles $\mathrm{A}_{1}$ and $A_{2}$, defined as the genes that increase and decrease trait expression, respectively, with frequencies $\mathrm{p}$ and $\mathrm{q}$. The mean genotypic values of half-sib families of the individuals $\mathrm{A}_{1} \mathrm{~A}_{1}, \mathrm{~A}_{1} \mathrm{~A}_{2}$ and $\mathrm{A}_{2} \mathrm{~A}_{2}$, are

$\overline{\mathrm{G}}_{\mathrm{OA}_{1} \mathrm{~A}_{1}}=\mathrm{M}+\mathrm{q} \alpha=\mathrm{M}+\frac{1}{2} \mathrm{~A}_{11}$

$\overline{\mathrm{G}}_{\mathrm{OA}_{1} \mathrm{~A}_{2}}=\mathrm{M}+\frac{1}{2}(\mathrm{q}-\mathrm{p}) \alpha=\mathrm{M}+\frac{1}{2} \mathrm{~A}_{12}$

$\overline{\mathrm{G}}_{\mathrm{OA}_{2} \mathrm{~A}_{2}}=\mathrm{M}-\mathrm{p} \alpha=\mathrm{M}+\frac{1}{2} \mathrm{~A}_{22}$

where, $M=m+(p-q) a+2 p q d$ is the genotypic mean of the population and $\mathrm{A}$ is the additive genetic value of the common parent, which is an individual in the population; $\mathrm{m}$ is the mean of the genotypic values of the homozygotes; $a$ is the difference between the genotypic value of $A_{1} A_{1}$ and $\mathrm{m}$; $\mathrm{d}$ is the difference between the genotypic value of the heterozygote and $\mathrm{m}$.

In relation to the $i$-th locus, $A_{i}=2 q_{i} \alpha_{i}$, if the individual is homozygous for the gene that increases the expression of the trait; $A_{i}=\left(q_{i}-p_{i}\right) \alpha_{i}$, if it is heterozygous; or $A_{i}=-2 p_{i} \alpha_{i}$, if the individual is homozygous for the gene that reduces the trait expression. The parameters $p_{i}$ and $\mathrm{q}_{\mathrm{i}}$ are the allele frequencies and $\alpha_{\mathrm{i}}=\mathrm{a}_{\mathrm{i}}+\left(\mathrm{q}_{\mathrm{i}}-\mathrm{p}_{\mathrm{i}}\right) \mathrm{d}_{\mathrm{i}}$ is the average effect of the gene substitution. Thus, assuming that genotypic value and environmental effect are independent random variables, the covariance between mean phenotypic value of half-sib family and the additive genetic value of its common parent is

$$
\begin{aligned}
\operatorname{Cov}\left(\overline{\mathrm{P}}_{\mathrm{HSF}}, \mathrm{A}\right) & =\operatorname{Cov}\left(\overline{\mathrm{G}}_{\mathrm{HSF}}, \mathrm{A}\right)=\mathrm{p}^{2}(\mathrm{q} \alpha)(2 \mathrm{q} \alpha) \\
& +2 \mathrm{pq}\left[\frac{1}{2}(\mathrm{q}-\mathrm{p}) \alpha\right][(\mathrm{q}-\mathrm{p}) \alpha]+\mathrm{q}^{2}(-\mathrm{p} \alpha)(-2 \mathrm{p} \alpha) \\
& =\mathrm{pq} \alpha^{2}=\frac{1}{2} \sigma_{\mathrm{A}}^{2}
\end{aligned}
$$

Considering $\mathrm{k}$ genes, we have

$\operatorname{Cov}\left(\overline{\mathrm{P}}_{\mathrm{HSF}}, \mathrm{A}\right)=\sum_{\mathrm{i}=1}^{\mathrm{k}} \mathrm{p}_{\mathrm{i}} \mathrm{q}_{\mathrm{i}} \alpha_{\mathrm{i}}^{2}=\frac{1}{2} \sigma_{\mathrm{A}}^{2}$

Defining $\sigma_{\mathrm{PbHSF}}^{2}$ as the variance of the phenotypic means of the half-sib families, the correlation between phenotypic value of half-sib family and the additive genetic value of its common parent is

$$
\rho_{\overline{\mathrm{P}}_{\mathrm{HSF}}, \mathrm{A}}=\frac{(1 / 2) \sigma_{\mathrm{A}}^{2}}{\sqrt{\sigma_{\mathrm{PbHSF}}^{2} \sigma_{\mathrm{A}}^{2}}}=\sqrt{\frac{(1 / 4) \sigma_{\mathrm{A}}^{2}}{\sigma_{\mathrm{PbHSF}}^{2}}}=\sqrt{\mathrm{h}^{2}}
$$

where $\mathrm{h}^{2}$ is the narrow sense heritability at half-sib family level.

Therefore, when the estimate of this heritability is high, a family with superior phenotypic mean should have a common parent with superior additive genetic value. In this case, when selecting the best families, the breeder ought to be selecting the common parents with the greatest number of desirable genes. Consequently, the recombination of progenies derived from these parents will assure a higher frequency of favorable genes in the improved population, comparatively to the initial one. 
On the other hand, if the heritability estimate is small, the phenotypic mean of the family cannot be a good indicator of the quality of the additive genetic value of the common parent, hindering the selection process. When selecting the superior families, the breeder is not necessarily selecting the common parents with the greater number of desirable genes. Therefore, there is no certainty of increasing their frequencies in the population after recombination.

\subsection{Correlation between full-sib family phenotypic value and the mean of the additive genetic values of its parents}

Consider first the locus of the alleles $\mathrm{A}_{1}$ and $\mathrm{A}_{2}$. The mean genotypic values of the full-sib families are

$$
\begin{aligned}
\overline{\mathrm{G}}_{\mathrm{OA}_{1} \mathrm{~A}_{1} \times \mathrm{A}_{1} \mathrm{~A}_{1}} & =\mathrm{M}+2 \mathrm{q} \alpha-2 \mathrm{q}^{2} \mathrm{~d}=\mathrm{M}+\mathrm{A}_{11}+\mathrm{D}_{11} \\
\overline{\mathrm{G}}_{\mathrm{OA}_{1} \mathrm{~A}_{1} \times \mathrm{A}_{2} \mathrm{~A}_{2}} & =\mathrm{M}+(\mathrm{q}-\mathrm{p}) \alpha+2 \mathrm{pqd} \\
& =\mathrm{M}+\frac{1}{2} \mathrm{~A}_{11}+\frac{1}{2} \mathrm{~A}_{22}+\frac{1}{2} \mathrm{D}_{11}+\frac{1}{2} \mathrm{D}_{22}+\mathrm{d} \\
\overline{\mathrm{G}}_{\mathrm{OA}_{1} \mathrm{~A}_{1} \times \mathrm{A}_{2} \mathrm{~A}_{2}} & =\mathrm{M}+(\mathrm{q}-\mathrm{p}) \alpha+2 \mathrm{pqd} \\
& =\mathrm{M}+\frac{1}{2} \mathrm{~A}_{11}+\frac{1}{2} \mathrm{~A}_{22}+\frac{1}{2} \mathrm{D}_{11}+\frac{1}{2} \mathrm{D}_{22}+\mathrm{d} \\
\overline{\mathrm{G}}_{\mathrm{OA}_{1} \mathrm{~A}_{2} \mathrm{XA}_{1} \mathrm{~A}_{2}} & =\mathrm{M}+(\mathrm{q}-\mathrm{p}) \alpha+\frac{1}{2}(4 \mathrm{pq}-1) \mathrm{d} \\
& =\mathrm{M}+\mathrm{A}_{12}+\mathrm{D}_{12}-\frac{1}{2} \mathrm{~d} \\
\overline{\mathrm{G}}_{\mathrm{OA}_{1} \mathrm{~A}_{2} \mathrm{XA}_{2} \mathrm{~A}_{2}} & =\mathrm{M}+\frac{1}{2}(1-4 \mathrm{p}) \alpha+\mathrm{p}(\mathrm{q}-\mathrm{p}) \mathrm{d} \\
& =\mathrm{M}+\frac{1}{2} \mathrm{~A}_{12}+\frac{1}{2} \mathrm{~A}_{22}+\frac{1}{2} \mathrm{D}_{12}+\frac{1}{2} \mathrm{D}_{22} \\
\overline{\mathrm{G}}_{\mathrm{OA}_{2} \mathrm{~A}_{2} \times \mathrm{AA}_{2} \mathrm{~A}_{2}} & =\mathrm{M}-2 \mathrm{p} \alpha-2 \mathrm{p}^{2} \mathrm{~d}=\mathrm{M}+\mathrm{A}_{22}+\mathrm{D}_{22}
\end{aligned}
$$

The covariance between mean genotypic value of full-sib family and the mean of the additive genetic values of its parents is where A and A' refer to the additive genetic values of the parents, which are individuals in the base population; $\mathrm{A}_{11}$ and $\mathrm{D}_{11}=-2 \mathrm{q}^{2} \mathrm{~d}, \mathrm{~A}_{12}$ and $\mathrm{D}_{12}=2 \mathrm{pqd}$, and $\mathrm{A}_{22}$ and $\mathrm{D}_{22}=-$ $2 \mathrm{p}^{2} \mathrm{~d}$ are, respectively, the additive and due to dominance genetic values of the individuals $\mathrm{A}_{1} \mathrm{~A}_{1}, \mathrm{~A}_{1} \mathrm{~A}_{2}$ and $\mathrm{A}_{2} \mathrm{~A}_{2}$.

For k genes,

$\operatorname{Cov}\left(\overline{\mathrm{G}}_{\mathrm{FSF}}, \frac{\mathrm{A}+\mathrm{A}^{\prime}}{2}\right)=\sum_{\mathrm{i}=1}^{\mathrm{k}} \mathrm{p}_{\mathrm{i}} \mathrm{q}_{\mathrm{i}} \alpha_{\mathrm{i}}^{2}=\frac{1}{2} \sigma_{\mathrm{A}}^{2}$

Admitting that the genotypic individual value in the base population and the effect due to environment are independent variables and defining $\sigma_{\mathrm{PbFF}}^{2}$ as the variance of the phenotypic means of the full-sib families, the correlation between mean phenotypic value of full-sib family and the mean of the additive genetic values of its parents is

$\rho_{\overline{\mathrm{P}}_{\mathrm{FSF}}, \overline{\mathrm{A}}}=\frac{\operatorname{Cov}\left(\overline{\mathrm{G}}_{\mathrm{FSF}}, \frac{\mathrm{A}+\mathrm{A}^{\prime}}{2}\right)}{\sqrt{\sigma_{\mathrm{PbSF}}^{2}(1 / 2) \sigma_{\mathrm{A}}^{2}}}=\sqrt{\frac{(1 / 2) \sigma_{\mathrm{A}}^{2}}{\sigma_{\mathrm{PbFSF}}^{2}}}=\sqrt{\mathrm{h}^{2}}$

since

$\mathrm{V}\left(\frac{\mathrm{A}+\mathrm{A}^{\prime}}{2}\right)=\sum_{\mathrm{i}=1}^{\mathrm{k}} \mathrm{V}\left(\frac{\mathrm{A}_{\mathrm{i}}+\mathrm{A}_{\mathrm{i}}^{\prime}}{2}\right)=\sum_{\mathrm{i}=1}^{\mathrm{k}} \mathrm{p}_{\mathrm{i}} \mathrm{q}_{\mathrm{i}} \alpha_{\mathrm{i}}^{2}=\frac{1}{2} \sigma_{\mathrm{A}}^{2}$

Therefore, the narrow sense heritability at full-sib family level $\left(\mathrm{h}^{2}\right)$ is the square of the correlation coefficient between the phenotypic value of family and the mean of the additive genetic values of its parents. Thus, a large estimate of this heritability implies that selection based on family phenotypic means should be efficient to identify pairs of parents with superior additive genetic mean values. When selecting the best families, based on a trait with high narrow sense heritability, the breeder should be selecting the pairs of parents with superior mean

$$
\begin{aligned}
\operatorname{Cov}\left(\bar{G}_{\mathrm{FSF}}, \frac{\mathrm{A}+\mathrm{A}^{\prime}}{2}\right) & =\mathrm{p}^{4}\left(\mathrm{M}+\mathrm{A}_{11}+\mathrm{D}_{11}\right)\left(\mathrm{A}_{11}\right)+4 \mathrm{p}^{3} \mathrm{q}\left(\mathrm{M}+\frac{1}{2} \mathrm{~A}_{11}+\frac{1}{2} \mathrm{~A}_{12}+\frac{1}{2} \mathrm{D}_{11}+\frac{1}{2} \mathrm{D}_{12}\right)\left(\frac{1}{2} \mathrm{~A}_{11}+\frac{1}{2} \mathrm{~A}_{12}\right) \\
& +2 \mathrm{p}^{2} \mathrm{q}^{2}\left(\mathrm{M}+\frac{1}{2} \mathrm{~A}_{11}+\frac{1}{2} \mathrm{~A}_{22}+\frac{1}{2} \mathrm{D}_{11}+\frac{1}{2} \mathrm{D}_{22}+\mathrm{d}\right)\left(\frac{1}{2} \mathrm{~A}_{11}+\frac{1}{2} \mathrm{~A}_{22}\right) \\
& +4 \mathrm{p}^{2} \mathrm{q}^{2}\left(\mathrm{M}+\mathrm{A}_{12}+\mathrm{D}_{12}-\frac{1}{2} \mathrm{~d}\right)\left(\mathrm{A}_{12}\right)+4 \mathrm{pq}^{3}\left(\mathrm{M}+\frac{1}{2} \mathrm{~A}_{12}+\frac{1}{2} \mathrm{~A}_{22}+\frac{1}{2} \mathrm{D}_{12}+\frac{1}{2} \mathrm{D}_{22}\right)\left(\frac{1}{2} \mathrm{~A}_{12}+\frac{1}{2} \mathrm{~A}_{22}\right) \\
& +\mathrm{q}^{4}\left(\mathrm{M}+\mathrm{A}_{22}+\mathrm{D}_{22}\right)\left(\mathrm{A}_{22}\right)-\mathrm{M} \cdot 0=\mathrm{pq \alpha} \alpha^{2}=\frac{1}{2} \sigma_{\mathrm{A}}^{2}
\end{aligned}
$$


additive genetic value and, therefore, with the greatest mean number of favorable genes. After recombination, using remnant seeds or inbred families, the resulting population should have the desirable genes with frequencies greater than those in the base population. This may not happen if the trait had low narrow sense heritability. In this case, selection of families with superior phenotypic values does not correspond to the selection of pairs of parents with greater mean number of favorable genes.

\subsection{Correlation between $S_{n}$ family phenotypic value and the additive genetic value of its parent}

Considering a base population structured in $\mathrm{S}_{\mathrm{n}}$ families after $\mathrm{n}$ generations of self-pollination without selection, mutation, migration and genetic drift, the inbreeding coefficient is

$$
\mathrm{F}=1-\left(\frac{1}{2}\right)^{\mathrm{n}}
$$

Regarding the alleles $\mathrm{A}_{1}$ and $\mathrm{A}_{2}$, the covariance between mean genotypic value of $S_{n}$ family and the additive genetic value of its parent is

$$
\begin{aligned}
\operatorname{Cov}\left(\overline{\mathrm{G}}_{\mathrm{S}_{\mathrm{n}} \mathrm{F}}, \mathrm{A}_{\mathrm{S}_{\mathrm{n}-1}}\right) & =\left(\mathrm{p}^{2}+\mathrm{pqF}_{\mathrm{n}-1}\right)\left(\mathrm{M}+\mathrm{A}_{11}+\mathrm{D}_{11}\right)\left(\mathrm{A}_{11}\right) \\
+ & 2 \mathrm{pq}\left(1-\mathrm{F}_{\mathrm{n}-1}\right)\left(\mathrm{M}+\mathrm{A}_{12}+\mathrm{D}_{12}-\frac{1}{2} \mathrm{~d}\right)\left(\mathrm{A}_{12}\right) \\
+ & \left(\mathrm{q}^{2}+\mathrm{pqF}_{\mathrm{n}-1}\right)\left(\mathrm{M}+\mathrm{A}_{22}+\mathrm{D}_{22}\right)\left(\mathrm{A}_{22}\right) \\
& -\left[\mathrm{M}-\operatorname{pqd}\left(1+\mathrm{F}_{\mathrm{n}-1}\right)\right] .0 \\
& =\left(1+\mathrm{F}_{\mathrm{n}-1}\right) \sigma_{\mathrm{A}}^{2}+\left(1+3 \mathrm{~F}_{\mathrm{n}-1}\right) \mathrm{pq}(\mathrm{p}-\mathrm{q}) \alpha d
\end{aligned}
$$

Since $F_{n-1}=-1+2 F$, then

$$
\operatorname{Cov}\left(\overline{\mathrm{G}}_{\mathrm{S}_{\mathrm{n}} \mathrm{F}}, \mathrm{A}_{\mathrm{S}_{\mathrm{n}-1}}\right)=2 \mathrm{~F} \sigma_{\mathrm{A}}^{2}+(6 \mathrm{~F}-2) \mathrm{pq}(\mathrm{p}-\mathrm{q}) \alpha \mathrm{d}
$$

In relation to $\mathrm{k}$ genes, it is shown that

$$
\begin{aligned}
\operatorname{Cov}\left(\overline{\mathrm{G}}_{\mathrm{S}_{\mathrm{n}} \mathrm{F}}, \mathrm{A}_{\mathrm{S}_{\mathrm{n}-1}}\right) & =2 \mathrm{~F}\left(2 \sum_{\mathrm{i}=1}^{\mathrm{k}} \mathrm{p}_{\mathrm{i}} \mathrm{q}_{\mathrm{i}} \alpha_{\mathrm{i}}^{2}\right)+(6 \mathrm{~F}-2) \sum_{\mathrm{i}=1}^{\mathrm{k}} \mathrm{p}_{\mathrm{i}} \mathrm{q}_{\mathrm{i}}\left(\mathrm{p}_{\mathrm{i}}-\mathrm{q}_{\mathrm{i}}\right) \alpha_{\mathrm{i}} \mathrm{d}_{\mathrm{i}} \\
= & 2 \mathrm{~F} \sigma_{\mathrm{A}}^{2}+(6 \mathrm{~F}-2) \sum_{\mathrm{i}=1}^{\mathrm{k}} \mathrm{p}_{\mathrm{i}} \mathrm{q}_{\mathrm{i}}\left(\mathrm{p}_{\mathrm{i}}-\mathrm{q}_{\mathrm{i}}\right) \alpha_{\mathrm{i}} \mathrm{d}_{\mathrm{i}}
\end{aligned}
$$

Assuming genotypic value and environment effect as independent variables, and defining $\sigma_{\mathrm{PbS}_{1} \mathrm{~F}}^{2}$ as the variance of the phenotypic means of the $S_{n}$ families, the correlation between mean phenotypic value of $\mathrm{S}_{\mathrm{n}}$ family and the additive genetic value of its parent is

$$
\begin{aligned}
& \rho_{\overline{\mathrm{P}}_{\mathrm{S}_{\mathrm{n}} \mathrm{F}}, \mathrm{A}_{\mathrm{S}_{\mathrm{n}-1}}}=\frac{\operatorname{Cov}\left(\overline{\mathrm{G}}_{\mathrm{S}_{\mathrm{n}} \mathrm{F}}, \mathrm{A}_{\mathrm{S}_{\mathrm{n}-1}}\right)}{\sqrt{\sigma_{\mathrm{PbS} \mathrm{n}_{\mathrm{n}}}^{2} 2 \mathrm{~F} \sigma_{\mathrm{A}}^{2}}} \\
& =\frac{2 F \sigma_{A}^{2}+(6 F-2) \sum_{i=1}^{k} p_{i} q_{i}\left(p_{i}-q_{i}\right) \alpha_{i} d_{i}}{\sqrt{\sigma_{P b S_{n} F}^{2} 2 F \sigma_{A}^{2}}} \\
& =\sqrt{\frac{2 F \sigma_{A}^{2}}{\sigma_{P b S_{n} F}^{2}}}+\frac{(6 F-2) \sum_{i=1}^{k} p_{i} q_{i}\left(p_{i}-q_{i}\right) \alpha_{i} d_{i}}{\sqrt{\sigma_{P b S_{n} F}^{2} 2 F \sigma_{A}^{2}}} \\
& =\sqrt{h^{2}}+\frac{\frac{(6 F-2)}{4 F} \operatorname{Cov}(A, D)_{F}}{\sqrt{\sigma_{P b S_{n} F}^{2} 2 F \sigma_{A}^{2}}}
\end{aligned}
$$

since the variance of the additive genetic values of the $\mathrm{S}_{\mathrm{n}-1}$ individuals is

$$
\begin{aligned}
\mathrm{V}\left(\mathrm{A}_{\mathrm{S}_{\mathrm{n}-1}}\right) & =\sum_{\mathrm{i}=1}^{\mathrm{k}} \mathrm{V}\left(\mathrm{A}_{\mathrm{S}_{\mathrm{n}-\mathrm{l}_{\mathrm{i}}}}\right)=\sum_{\mathrm{i}=1}^{\mathrm{k}}\left[\left(\mathrm{p}_{\mathrm{i}}^{2}+\mathrm{p}_{\mathrm{i}} \mathrm{q}_{\mathrm{i}} \mathrm{F}_{\mathrm{n}-1}\right)\left(\mathrm{A}_{11 \mathrm{i}}\right)^{2}\right. \\
& \left.+2 \mathrm{p}_{\mathrm{i}} \mathrm{q}_{\mathrm{i}}\left(1-\mathrm{F}_{\mathrm{n}-1}\right)\left(\mathrm{A}_{12 \mathrm{i}}\right)^{2}+\left(\mathrm{q}_{\mathrm{i}}^{2}+\mathrm{p}_{\mathrm{i}} \mathrm{q}_{\mathrm{i}} \mathrm{F}_{\mathrm{n}-1}\right)\left(\mathrm{A}_{22 \mathrm{i}}\right)^{2}\right] \\
& =\left(1+\mathrm{F}_{\mathrm{n}-1}\right) \sum_{\mathrm{i}=1}^{\mathrm{k}} 2 \mathrm{p}_{\mathrm{i}} \mathrm{q}_{\mathrm{i}} \alpha_{\mathrm{i}}^{2}=\left(1+\mathrm{F}_{\mathrm{n}-1}\right) \sigma_{\mathrm{A}}^{2}=2 \mathrm{F \sigma}_{\mathrm{A}}^{2}
\end{aligned}
$$

The parameter $\mathrm{h}^{2}$ is the narrow sense heritability at $S_{n}$ family level and $\operatorname{Cov}(A, D)_{F}=4 F \sum_{i=1}^{k} p_{i} q_{i}\left(p_{i}-q_{i}\right) \alpha_{i} d_{i}$ is the covariance between additive and due to dominance genetic values of the same individual in the population structured in $\mathrm{S}_{\mathrm{n}}$ families.

$$
\begin{aligned}
& \text { When } \mathrm{p}_{\mathrm{i}}=\mathrm{q}_{\mathrm{i}} \text { or } \mathrm{d}_{\mathrm{i}}=0 \text {, for all } \mathrm{i} \text {, } \\
& \qquad \rho_{\overline{\mathrm{P}}_{\mathrm{S}_{\mathrm{n}} \mathrm{F}}, \mathrm{A}_{\mathrm{S}_{\mathrm{n}-1}}=\sqrt{\mathrm{h}^{2}}}
\end{aligned}
$$

In the case of self-pollinated plants, the narrow sense heritability at $\mathrm{F}_{\mathrm{n}+2}(\mathrm{n} \geq 1)$ family level is the square of the correlation between phenotypic mean of family and the additive genetic value of its parent. Thus, the greater 
the heritability, the more efficient will be the identification of the parents with superior additive genetic value, on the basis of phenotypic means of families. When the trait considered for selection has a high estimate of narrow sense heritability, the selected families should have the favorable genes in greater frequency, since their parents should have superior additive genetic value, and therefore, a greater number of desirable genes.

In populations structured in $S_{n}$ families, the estimate of narrow sense heritability at family level could indicate whether the selection process will be efficient in increasing the frequency of the desirable genes. If the estimate is high, the genetic values due to dominance should represent a small fraction of the genotypic values and the residual variance should be reduced. Thus

$$
\begin{aligned}
\sigma_{\mathrm{GbS}_{\mathrm{n}} \mathrm{F}}^{2} & =2 F \sigma_{\mathrm{A}}^{2}+\left(3-6 \mathrm{~F}-\mathrm{F}^{2}\right) \sigma_{\mathrm{D}}^{2} \\
& +4(3 \mathrm{~F}-1) \sum_{\mathrm{i}=1}^{\mathrm{k}} \mathrm{p}_{\mathrm{i}} \mathrm{q}_{\mathrm{i}}\left(\mathrm{p}_{\mathrm{i}}-\mathrm{q}_{\mathrm{i}}\right) \alpha_{\mathrm{i}} \mathrm{d}_{\mathrm{i}}+(7 \mathrm{~F}-3) \sum_{\mathrm{i}=1}^{\mathrm{k}} \mathrm{p}_{\mathrm{i}} \mathrm{q}_{\mathrm{i}} \mathrm{d}_{\mathrm{i}}^{2} \\
& \cong 2 \mathrm{~F} \sigma_{\mathrm{A}}^{2}
\end{aligned}
$$

where $\sigma_{\mathrm{GbS}_{\mathrm{n}} \mathrm{F}}^{2}$ is the variance of the genotypic means of the $S_{n}$ families.

Therefore, when

$\sigma_{\mathrm{D}}^{2} \cong \sum_{\mathrm{i}=1}^{\mathrm{k}} \mathrm{p}_{\mathrm{i}} \mathrm{q}_{\mathrm{i}}\left(\mathrm{p}_{\mathrm{i}}-\mathrm{q}_{\mathrm{i}}\right) \alpha_{\mathrm{i}} \mathrm{d}_{\mathrm{i}} \cong \sum_{\mathrm{i}=1}^{\mathrm{k}} \mathrm{p}_{\mathrm{i}} \mathrm{q}_{\mathrm{i}} \mathrm{d}_{\mathrm{i}}^{2} \cong 0$, the narrow sense heritability at $\mathrm{S}_{\mathrm{n}}$ family level will be approximately the square of the correlation coefficient between phenotypic mean of family and the additive genetic value of its parent. When selecting the best families, the breeder should be choosing the parents with superior additive genetic value, and therefore, with more desirable genes. The frequencies of the favorable genes in the set of selected families should be higher than in the base population.

On the other hand, if the estimated heritability is small, the genetic variance due to dominance should represent an important part of the genotypic variance and, or, the residual variance should be high. In this case, the coefficient of correlation between the phenotypic mean of $S_{n}$ family and the additive genetic value of its parent will depend on the value of $\operatorname{Cov}(\mathrm{A}, \mathrm{D})_{\mathrm{F}}$, hindering any inference about the efficiency of selecting families with superior phenotypic means in increasing the frequencies of the favorable genes. When the trait is of low narrow sense heritability, due to dominance, and the covariance between additive and due to dominance genetic values of the same $S_{n}$ individual is positive and high, the correlation may be of high magnitude. In such case, the selection process can be efficient, in spite of the low heritability estimate. The reverse can also occur: in spite of the high heritability estimate, indicating efficient selection, the correlation between the phenotypic mean of $S_{n}$ family and the additive genetic value of its parent can be low or negative, since its value depends on the covariance between the additive and due to dominance genetic values.

\subsection{Correlation between phenotypic and genotypic mean values of same family}

For every type of family, if genotypic value and environmental effect are independent, random variables, the correlation between phenotypic $(\overline{\mathrm{P}})$ and genotypic $(\overline{\mathrm{G}})$ means of same family is

$$
\rho_{\overline{\mathrm{P}}, \overline{\mathrm{G}}}=\frac{\operatorname{Cov}(\overline{\mathrm{P}}, \overline{\mathrm{G}})}{\sqrt{\sigma_{\mathrm{PbF}}^{2} \sigma_{\mathrm{GbF}}^{2}}}=\sqrt{\frac{\sigma_{\mathrm{GbF}}^{2}}{\sigma_{\mathrm{PbF}}^{2}}}=\sqrt{\mathrm{h}_{\mathrm{b}}^{2}}
$$

where $\sigma_{\mathrm{GbF}}^{2}$ and $\sigma_{\mathrm{PbF}}^{2}$ are, respectively, the variances of the genotypic and phenotypic means of the families that can be obtained from the base population, and $h_{b}^{2}$ is the broad sense heritability at family level.

What is the merit of this heritability, normally estimated when selection units are full-sib or $\mathrm{S}_{\mathrm{n}}$ families, to analyze the selection efficiency? In other words, when the mean genotypic value of full-sib or $S_{n}$ family is an indicator of the superiority of the parents or $S_{n-1}$ plant in terms of frequency of favorable genes? For simplicity, we will consider the alleles $A_{1}$ and $A_{2}$ and the following degrees of dominance: (i) $\mathrm{d} / \mathrm{a}=2$ (overdominance); (ii) $\mathrm{d} / \mathrm{a}=1$ (complete dominance) $\mathrm{d} / \mathrm{a}=1 / 2$ (partial dominance); and (iv) d/a $=0$ (absence of dominance). Figures 1 to 4 should be used to compare the genotypic means of the three $S_{n}$ progenies that can be derived from any population in Hardy-Weinberg equilibrium (Parents $A_{1} A_{1} \times A_{1} A_{1}, A_{1} A_{2} \times A_{1} A_{2}$ and $A_{2} A_{2} \times A_{2} A_{2}$.

Assuming that broad sense heritability at full-sib family level is high, that $\mathrm{d} / \mathrm{a}=2$ (Figure 1) and that favorable gene increases trait expression (is dominant), the progeny of greater mean genotypic value is that with 
parents homozygous for the desirable and unfavorable alleles. In this situation, the frequency of the favorable gene in the superior families is $1 / 2$. Therefore, selection tends to have low efficiency compared to the maximum expected (selection of parents homozygous for the desirable gene). On the contrary, if the favorable gene decreases trait expression (is recessive), selection tends to have maximum efficiency since the progeny with the least genotypic mean is that from parents with the favorable gene fixed.

If there is complete dominance (Figure 2) and the favorable gene is dominant, selection tends to favor families with one parent homozygous for the desirable gene. Since its frequency in the selected families is $1 / 2$ or $3 / 4$ or 1 , selection will be efficient, but not quite reaching the maximum. The maximum efficiency is achieved when the favorable gene is recessive, because the parents of the progeny with the lowest genotypic mean will have this gene fixed.

Selection efficiency will be also maximum when dominance is partial or there is no dominance (Figures 3 and 4), no matter which allele is favorable. In these cases, the superior progeny (with the greatest or the smallest genotypic mean) is that from parents homozygous for the desirable gene.

In the case of $S_{n}$ family selection, if broad sense heritability at family level is high, with overdominance, in which the favorable gene is the dominant, the selected progenies tend to have frequency of favorable genes equal to 1 or $1 / 2$. Consequently, the efficiency will not be the highest. In other situations, including cases of overdominance in which the desirable gene is recessive, partial dominance, and absence of dominance, the selection tends to maximum efficiency, since families with superior genotypic mean are those from parents homozygous for the favorable gene (Figures 1 to 4 ).

Therefore, broad sense heritability at full-sib or $\mathrm{S}_{\mathrm{n}}$ family level can be used to analyze the selection efficiency since the family genotypic mean is, in general, a good to excellent indicator of the superiority of the parents or $\mathrm{S}_{\mathrm{n}-1}$ plant, with respect to frequency of the favorable genes. Disregarding loci with overdominance, and the desirable gene being dominant, if broad sense heritability at full-sib or $\mathrm{S}_{\mathrm{n}}$ family level is high, the selection of superior families should increase frequency of all other favorable genes.

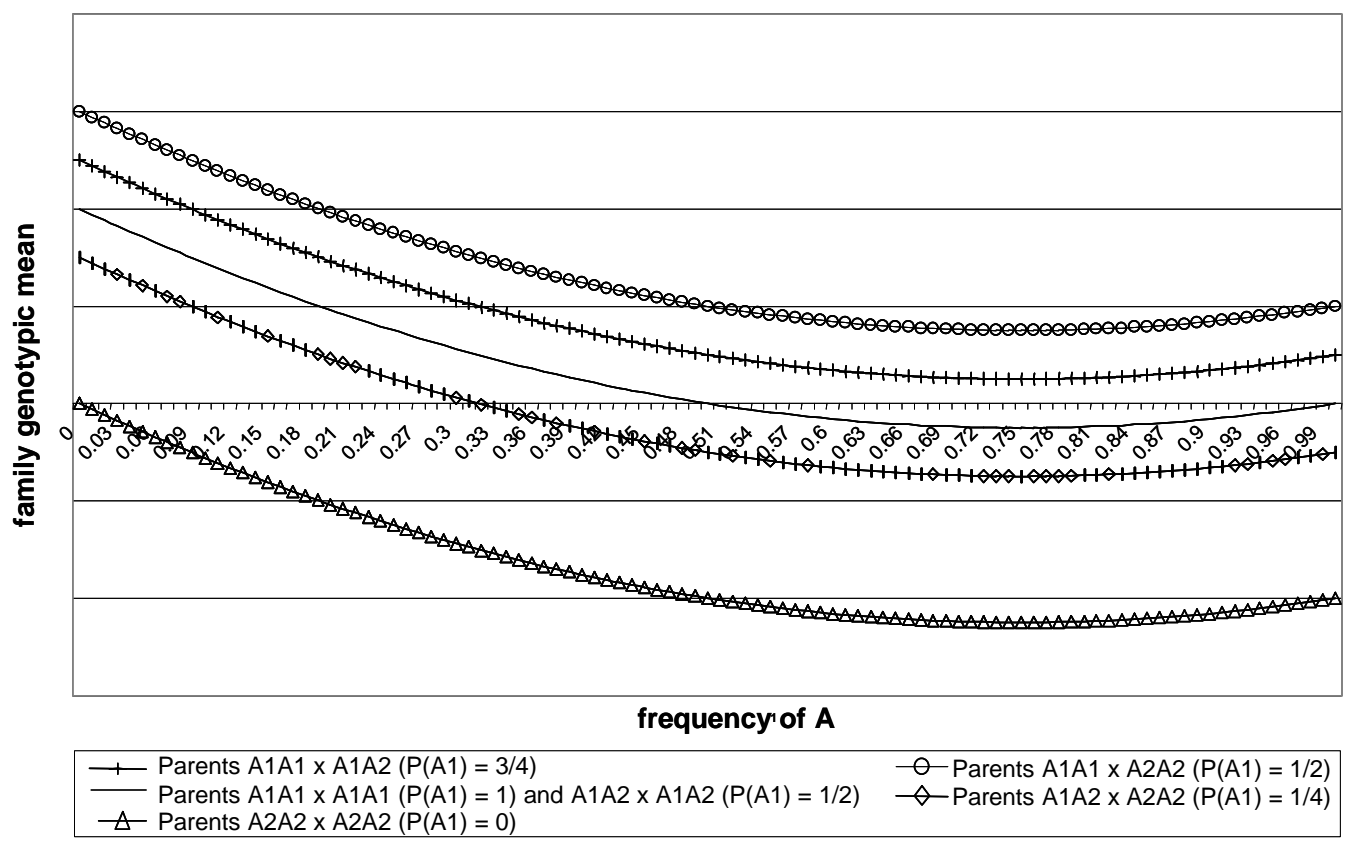

Figure 1 - Full-sib family genotypic means in Hardy-Weinberg equilibrium populations, except those with $p=0$ or 1 , considering one gene and overdominance $(\mathrm{d} / \mathrm{a}=2)$.

Figura 1 - Médias de famílias de irmãos completos em populações em equilíbrio de Hardy-Weinberg, exceto aquelas com $p=0$ ou 1 , considerando um gene e sobredominância $(d / a=2)$. 


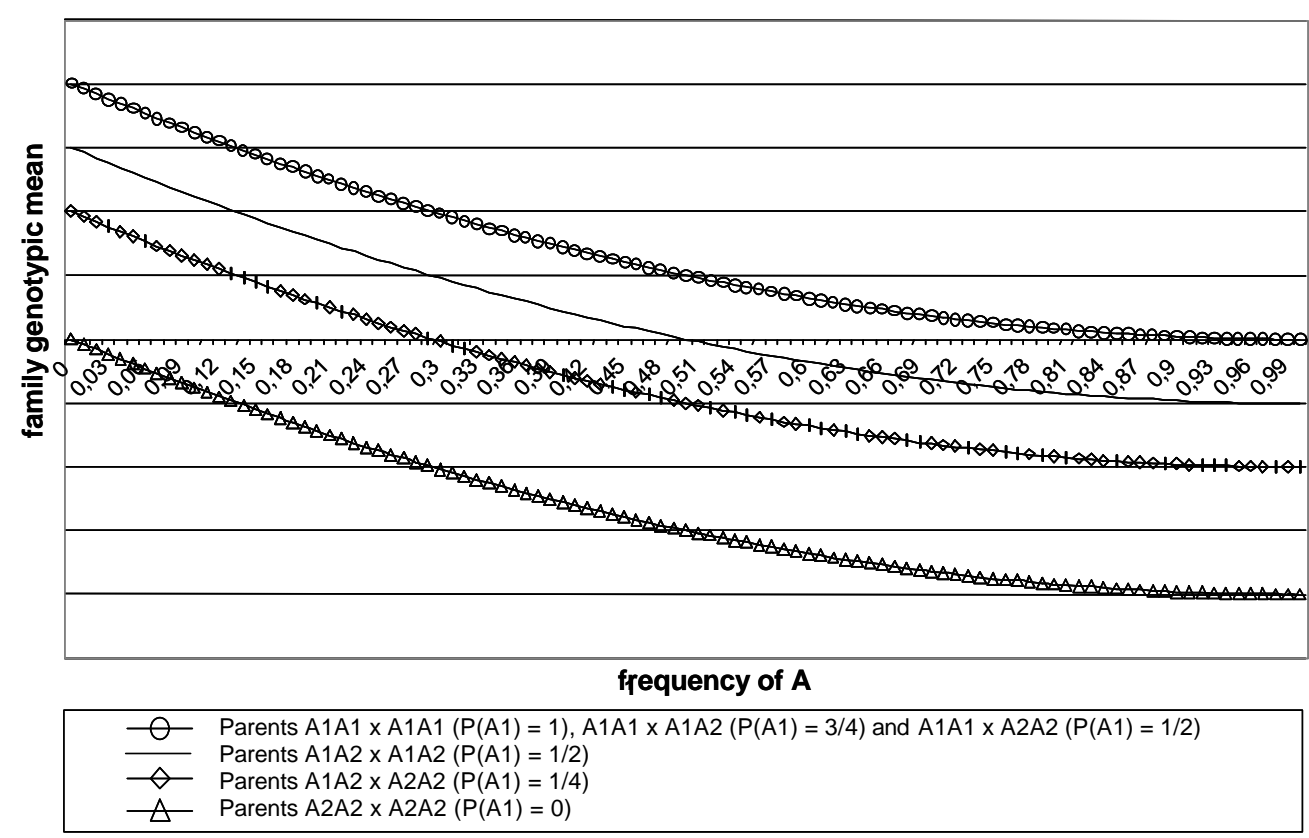

Figure 2 - Full-sib family genotypic means in Hardy-Weinberg equilibrium populations, except those with $\mathrm{p}=0$ or 1 , considering one gene and complete dominance $(\mathrm{d} / \mathrm{a}=1)$.

Figura 2 - Médias de famílias de irmãos completos em populações em equilíbrio de Hardy-Weinberg, exceto aquelas com $p=0$ ou 1, considerando um gene e dominância completa $(d / a=1)$.

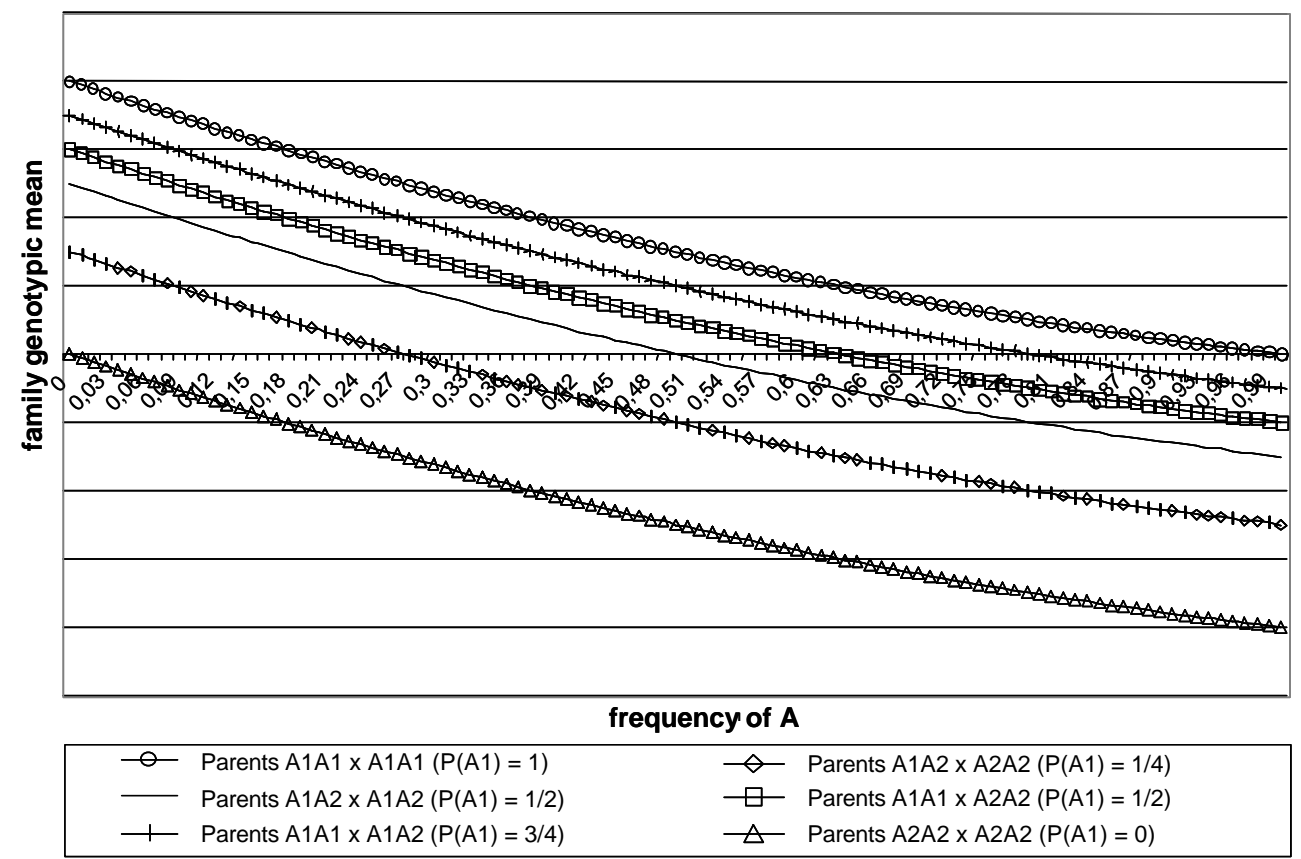

Figure 3 - Full-sib family genotypic means in Hardy-Weinberg equilibrium populations, except those with $\mathrm{p}=0$ or 1 , considering one gene and partial dominance $(\mathrm{d} / \mathrm{a}=1 / 2)$.

Figura 3 - Médias de famílias de irmãos completos em populações em equilíbrio de Hardy-Weinberg, exceto aquelas com $p=0$ ou 1, considerando um gene e dominância parcial ( $/ / a=1 / 2)$. 


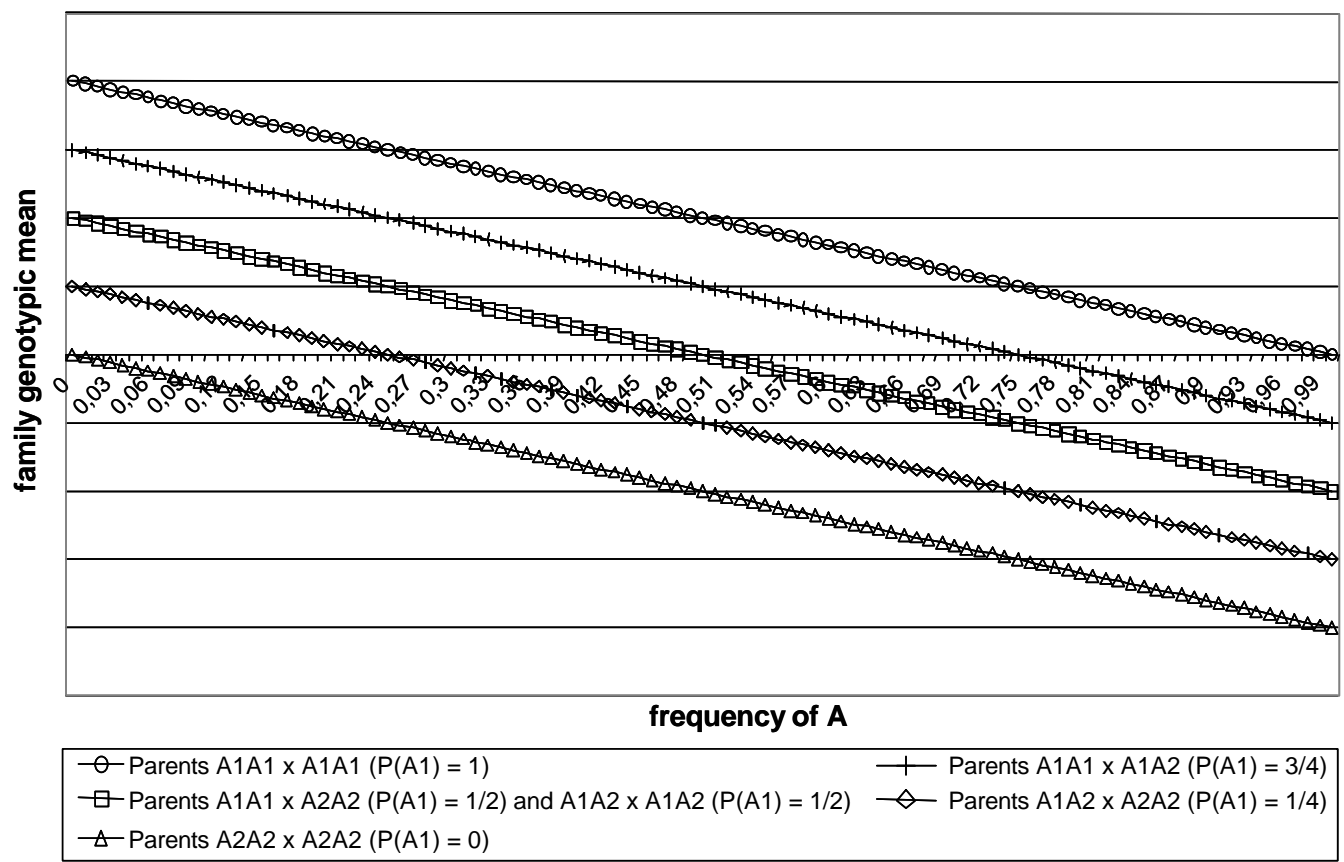

Figure 4 - Full-sib family genotypic means in Hardy-Weinberg equilibrium populations, except those with $\mathrm{p}=0$ or 1 , considering one gene and absence of dominance $(\mathrm{d} / \mathrm{a}=0)$.

Figura 4 - Médias de famílias de irmãos completos em populações em equilíbrio de Hardy-Weinberg, exceto aquelas com $p=0$ ou 1, considerando um gene e ausência de dominância $(d / a=0)$.

\section{CONCLUSIONS}

Plant breeders must analyze narrow sense heritabilities at family level, in order to evaluate the efficiency of the selection process based on family phenotypic means. Preferably, and if adequate, the related correlation should be analyzed, since it is always higher than the heritability. Broad sense heritability can alternatively be used, but it is important to note that selection based on genotypic value cannot be as efficient as the selection based on additive genetic value.

\section{REFERENCES}

DUDLEY, J. W.; MOLL, R. H. Interpretation and use of estimates of heritabilities and genetic variances in plant breeding. Crop Science, n. 9, p. 257-262, 1969.
FALCONER, D. S.; MACKAY, T. F. C. Introduction to quantitative genetics. 4.ed. England : Longman, 1996. $464 \mathrm{p}$.

HALLAUER, A. R.; MIRANDA FILHO, J. B.

Quantitative genetics in maize breeding. Ames: Iowa State University Press, 1981. 468 p.

HANSON, W. D. Heritability. In: HANSON, W. D.; ROBINSON, H. F. (Eds.) Statistical genetics and plant breeding. Washington: National Academy of Sciences National Research Council, 1963. p. 125-140.

NYQUIST, W. E. Estimation of heritability and prediction of selection response in plant populations. Critical Reviews in Plant Sciences, n. 3, p. 235-322, 1991.

WRICKE, G.; WEBER, W. E. Quantitative genetics and selection in plant breeding. Berlin: Walter de Gruyter, 1986. $406 \mathrm{p}$. 